\title{
Solid Waste Characterization and Recycling Potential for Decan and Junik Municipality
}

* Univeristy Haxhi Zeka, str. UCK, 30000, Peja;

e-mail: albona.shala@unhz.eu

Keywords:

Waste, recycling, waste characterization, Kosovo

\section{Abstract}

Solid waste management is one of the most environmentally challenging issues in Kosovo. Still there is not full coverage with waste collection service, there are a lot of illegal dumpsites, very few recycling initiatives and so on. In the study, we have investigated waste generation per day, solid waste characterization and recycling potential in two municipalities of Kosovo - Decan and Junik. The data were collected during 10 days in different locations in order to cover the whole territory of both municipalities. Both municipalities generate almost the same amount of waste per capita/kg/day, have very similar waste characterization when half of the waste is biodegradable. Only by selling recycling type of waste to waste treatment companies both of the municipalities generate incomes that can be used to improve waste management in their territory. So, as far as these municipalities start with waste separation, better waste management will be within their territory.

(c) IOŚ-PIB

\section{INTRODUCTION}

Waste management in Kosovo has begun relatively late, although the origins of waste collection date back to 1947. Rapidly growing populations, rapid economic growth and rise in community living standards have accelerated the generation rate of municipal solid waste causing its management to be a major worldwide challenge [Seo et al. 2004]. Different researchers have found that the amount of waste generated is proportional to its population and the mean living standards of the people [Wertz, 1976; Grossmann et al. 1974]. Medina (1997) related waste generation rates to income of people. Waste management services initially provided largely through primitive tools such as horse-drawn carriages, and later, these services have been advanced by technical means such as tractors and trucks. But over time, the waste management system has improved in collection and quality of the service [State of Waste Report, 2008]. Having in place a suitable waste management system, the setting of a new waste system is not an easy task for any of the new counties such is Kosovo. Strange (2002) argues that to face the problems associated with waste management, different strategies such as plans and programs, technical standards and mandatory regulations, financial strategies (taxes and financial incentives) and persuasive strategies (information campaigns, public relationships and environmental management systems) must be implemented to minimize waste. However, the current solid waste management system in Kosovo is in a bad situation. Waste collection service is still not provided in all the territories of Kosovo, therefore, uncollected waste that is discarded or burned has a negative impacts on human health, water, air, soil and biodiversity [State of Waste Report, 2008]. Waste separation at source is only piloted in some municipalities, and the collection of recyclables is still only done by the informal sector.

Municipal waste collection, transport and final disposal to a sanitary landfill is one of the basic services that a municipality provides for all those working and living within its territory. The overall service coverage by the end of 2016 of Kosovo stands at $57.8 \%$. The region with the highest coverage rate is the Prizren region (78.9\%), and the highest coverage of the rural area is in the Prizren region as well $(71.4 \%)$. The region with the lowest coverage rate is the Gjakovë region (37.6\%), and the same Gjakovë region has also the lowest coverage of the rural area (16.5\%) (State of waste report, 2018).

The amount of waste disposed in the Kosovo Landfill Management Company operated landfills for the year 2017 was 280,334.55 ton. On the other sanitary landfills, the amount of waste deposited in 2017, was approximately $111,951.55$ tons. This makes $392,286.10$ ton/year (2017) disposed in sanitary landfills (State of waste report, 2018). Based on the 2016 data from the Statistical Agency of Kosovo, 53,218 tons of waste was processed by the private businesses and 10,674 tons of waste was exported, for 
the recycling industry in other countries. 62,461 tons was collected by the companies, which represented $\sim 15 \%$ of the total amount of waste collected $(\sim 416,378.9$ tons in the year 2017) and the amount of waste that was exported in comparison to the total amount of collected waste was only $2.6 \%$.

The characterization of solid waste is the first step in the planning of integrated waste management. Knowing the composition of the waste allows for defining the strategies for separation, collection and frequency of collection for recycling [Armijo de Vega et al. 2003].

The aim of this study was to investigate the waste characterization on two municipalities of Kosovo, Decan and Junik, and the possibility and cost benefits of waste treatment in these two municipalities.

\section{METHODS}

This study were carried out in Deçan and Junik Municipalities, which are located in the western part of Kosovo. Deçan municipality has 40,019 inhabitants and covers an area of $371 \mathrm{~km}^{2}$. In Junik municipality, there are 6364 inhabitants within total surface area of $86.2 \mathrm{~km}^{2}$ [Statistical Office, 2021]. The study on characterization of solid waste in two municipalities Deçan and Junik consisted of four main stages: (1) estimate of the daily solid waste generation, (2) solid waste characterization sampling, (3) data capture and analysis of the amounts and types of wastes generated on two municipalities and (4) economic benefits from possible waste recycling.

\subsection{Estimation of daily solid waste generation}

The estimate of daily generation was carried out based on the weight of solid waste collected by public and private companies in both municipalities. All the waste generated in these municipalities was collected by the public and private companies. In order to determine the weight of the solid waste generated within the municipalities, first the weight of the empty truck had to be known. The difference between the weight of the full truck and the empty truck provided the weight of the load. That information was used to calculate the average weight of each load.

\subsection{Solid waste characterization sampling}

The samples were taken from five different points of generation in both municipalities: three of them were in the rural area and two in urban area. These five points in each municipality are representative because they cover all territories of the municipalities. The characterization of the solid waste was carried out using the modified methodology for the characterization of household waste proposed by Buenrostro-Delgado [2001]. Various authors [Buenrostro-Delgado 2001; Shah 2000; INE 1999] have reported that there is a seasonal variability in the composition and the amount of municipal solid waste (generation increasing during the hot season). The waste analysed in this study was generated in two municipalities; nevertheless, one should assume that there will be variations all along the year similar to those reported for municipal solid waste. During the warm season, there is a greater consumption of beverages and bottled water. This implies a greater generation of waste from the containers in which they are sold. On the other hand, tree pruning and grass mowing is more intensive during May and August, which lead to a greater generation of waste from gardens. It is believed that, if the sampling is carried out during another time of the year, the proportions of waste will change, so, if there is a desire to find out the trend of each one of the categories all along the year, at least one sampling per season should be carried out. This study was carried out during early spring and summer. Samples were taken during 10 consecutive days in spring and 10 consecutive days in summer. The samples on the first day were trial samplings. This trial sampling helped to unify criteria for data collection and for the identification of the solid waste. The results from the solid waste analysed during the following 10 days are the ones reported in this paper.

\subsection{Data collection and analysing}

The characterization data were collected by using the format of data collection by sub-products.

\subsection{Economic benefits from possible waste recycling}

When we have the data of waste characterization, then an economical approach was used to calculate the benefits that municipalities could have if they start recycling their waste. The calculation was made only if municipalities separate and sell different types of waste to waste treatment companies, which is the very first step of municipalities to start a better waste management. Selling prices for each of the waste type were collected from waste treatment companies in Kosovo.

\section{RESULTS AND DISCUSSION}

\subsection{Decan Municipality}

During 2018, total quantity of waste collected was 2363 tons. The annual average kg/capita/year was $206 \mathrm{~kg} /$ year, while the average $\mathrm{kg} / \mathrm{capita} /$ day was $0.56 \mathrm{~kg} /$ day. The daily average of waste generation in Decan Municipality for 2018 was $6473.97 \mathrm{~kg}$. During this study, in total, 2800 $\mathrm{kg}$ of waste were segregated. Total amount that were collected in 20 days corresponds to $43.5 \%$ daily average of waste generated each day in Decan Municipality. The waste analysed from the five sources provided the results shown in Table 1. As we can see, more than half of the waste generated is organic waste, then the largest amount are glass and so one. Similar results were found in other 
Table 1. Waste characterization in Decan municipality

\begin{tabular}{|c|c|c|} 
Nr. & Waste type & $\begin{array}{c}\text { Deçan } \\
(\%)\end{array}$ \\
\hline 1 & Organic waste & 53.62 \\
\hline 2 & Paper and Cartoon & 4.5 \\
\hline 3 & Plastics & 5 \\
\hline 4 & Glass & 14.28 \\
\hline 5 & Textile & 10.5 \\
\hline 6 & Metal & 2.8 \\
\hline 8 & Hazardous waste & 0.3 \\
\hline 9 & Construction and Demolition waste & 1 \\
\hline 10 & Others & 8 \\
\hline & Total & $\mathbf{1 0 0}$ \\
\hline
\end{tabular}

Table 2. Yearly amount of recycled waste in Decan municipality

\begin{tabular}{|c|c|}
$\begin{array}{c}\text { Recycled } \\
\text { waste }\end{array}$ & $\begin{array}{c}\text { Recycled waste amount } \\
\text { ton/year }\end{array}$ \\
\hline Plastics & 118.15 \\
\hline Paper & 106.33 \\
\hline Glass & 337.43 \\
\hline Metal & 66.16 \\
\hline Total & $\mathbf{6 2 8 . 0 7}$ \\
\hline
\end{tabular}

different countries [AbdAlqader, Hamad 2012; Babatunde et al. 2013]

If we convert the type of waste percentages in amount of ton/year, we realize that in Decan municipality, the waste that can be recycled is 628.07 ton (Table 2 ).

Based on the prices that we collected from different waste treatment companies, we calculated that if these amount of waste will be sold to waste treatment companies in Kosovo then municipality will earn 109,235.16 euro annually (Table 3).

\subsection{Junik Municipality}

During 2018, total quantity collected was 360 tons. The annual average $\mathrm{kg} / \mathrm{capita} /$ year was $200 \mathrm{~kg} /$ year, while the average $\mathrm{kg} / \mathrm{capita} /$ day was $0.54 \mathrm{~kg} /$ day. The daily average of waste generation in Junik Municipality for 2018 was $986.30 \mathrm{~kg}$.

During this study, in total, $315 \mathrm{~kg}$ of waste were segregated. Total amount that were collected in 20 days corresponds to $32 \%$ of daily average of waste generated each day in Junik Municipality. The waste analysed from the five sources provided the results shown in Table 4. As we can see, more than half of the waste generated is organic waste, then
Table 3. Economic value of recycled waste in Decan municipality

\begin{tabular}{|c|c|c|c|c|}
$\begin{array}{c}\text { Type of } \\
\text { waste }\end{array}$ & $\begin{array}{c}\text { Amount// } \\
\mathbf{k g}\end{array}$ & $\begin{array}{c}\text { Recycled } \\
\text { amount/ } \\
\mathbf{7 0 \% * *}\end{array}$ & Price* & $\begin{array}{c}\text { Economic } \\
\text { value }\end{array}$ \\
\hline Plastics & 118150 & 82705 & 0.40 & $33082 €$ \\
\hline Paper & 106330 & 74431 & 0.04 & $2977.24 €$ \\
\hline Glass & 337430 & 236201 & 0.20 & $47240.2 €$ \\
\hline Metal & 66160 & 46312 & 0.56 & $25934.72 €$ \\
\hline Total & & & & $\mathbf{1 0 9 2 3 4 . 1 6} €$ \\
\hline
\end{tabular}

* Price per kg when you sell recycled waste to recycling companies (data from Kosovo Environmental Protection Agency)

** Amount is author assumption based on filed observation

Table 4. Waste characterization in Junik municipality

\begin{tabular}{|c|c|c|} 
Nr. & Waste type & $\begin{array}{c}\text { Deçan } \\
(\%)\end{array}$ \\
\hline 1 & Organic waste & 52.4 \\
\hline 2 & Paper and Cartoon & 5 \\
\hline 3 & Plastics & 5.2 \\
\hline 4 & Glass & 13.4 \\
\hline 5 & Textile & 11 \\
\hline 6 & Metal & 2.4 \\
\hline 8 & Hazardous waste & 0.4 \\
\hline 9 & Construction and Demolition waste & 1.3 \\
\hline 10 & Others & 9 \\
\hline & Total & $\mathbf{1 0 0}$ \\
\hline
\end{tabular}

the largest amount are glass and so on. As we mentioned earlier, same results were found in different countries [AbdAlqader, Hamad 2012; Babatunde et al. 2013].

If we convert the type of waste percentages in the amount of ton/year, we realize that in Junik municipality, the amount of waste that can be recycled is 93.6 (table 5).

Again based on prices that we collected from different waste treatment companies, we calculated that if these amounts of waste will be sold to waste treatment companies in Kosovo then municipality will earn 15,886.08 euro annually (Table 6). As Roland Berger Strategy Consultant Report stated that the global market for environmental technology was about $\$ 1,370$ million in 2008; and it was projected to be $\$ 2,740$ million in 2020 . Around $\$ 41$ million in 2008 and $\$ 63$ million in 2020 were money that comes from waste management and recycling [Visvanathan 2011].

In order to avoid landfilling as is happening in Kosovo right now, several waste treatments are possible and they are all 
Table 5. Yearly amount of recycled waste in Junik municipality

\begin{tabular}{|c|c|}
\hline $\begin{array}{c}\text { Recycled } \\
\text { waste }\end{array}$ & $\begin{array}{c}\text { Recycled waste amount } \\
\text { ton/year }\end{array}$ \\
\hline Plastics & 18.72 \\
\hline Paper & 18 \\
\hline Glass & 48.24 \\
\hline Metal & 8.64 \\
\hline Total & $\mathbf{9 3 . 6}$ \\
\hline
\end{tabular}

better with respect to environmental impact, use of energy resources and economy [Erikson et al 2005]. Knowing that the most recycled material in overall selling value is plastic, which comprised $36 \%$ of total selling value, and based on the data from this study, we as a young country have to start from it. In the industrial market and international trading, recycled plastic materials are very competitive and meet a high demand. They can be traded as clean shreds or pellets of recycled plastic [Matter 2013]. Daily different approaches are suggested to increase waste separation such as economic intensive and environmental awareness [Matter et al. 2013]. Collecting and recycling waste in these two municipalities by Regional Waste collection companies will help authorities to increase incomes, and in principle, the quality of waste service.

\section{CONCLUSION}

The daily generation of solid waste in Decan and Junik is very similar, that is, $0.56 \mathrm{~kg} / \mathrm{capita} /$ day and $0.54 \mathrm{~kg} / \mathrm{capita} /$ day, respectively. Waste characterization if very similar in both municipalities and but vary from state waste
Table 6. Economic value of recycled waste in Decan municipality

\begin{tabular}{|c|c|c|c|c|}
\hline $\begin{array}{c}\text { Type of } \\
\text { waste }\end{array}$ & $\begin{array}{c}\text { Amount/ } \\
\mathbf{k g}\end{array}$ & $\begin{array}{c}\text { Recycled } \\
\text { amount/ } \\
\mathbf{7 0 \% * *}\end{array}$ & Price** & $\begin{array}{c}\text { Economic } \\
\text { value }\end{array}$ \\
\hline Plastics & 18720 & 13104 & 0.40 & 5241.6 \\
\hline Paper & 18000 & 12600 & 0.04 & 504 \\
\hline Glass & 42240 & 33768 & 0.20 & 6753.6 \\
\hline Metal & 8640 & 6048 & 0.56 & 3386.88 \\
\hline Total & & & & $\mathbf{1 5 8 8 6 . 0 8}$ \\
\hline
\end{tabular}

* Price per kg when you sell recycled waste to recycling companies (data from Kosovo Environmental Protection Agency)

* Amount is author assumption based on filed observation

characterization. Based on the State of waste report from 2008 , the characterization is as follows: organic waste (35\%), glass $21 \%$, wood $11 \%$, plastics $9.4 \%$, metals $9.3 \%$, textile $8.2 \%$, paper $4.6 \%$ [State of waste report, 2008]. Waste from both municipalities shows high potential for recycling. The highest type of waste is organic waste that can be used to produce compost, then glass, plastics and so one. With a simple calculation, we can see that both municipalities can generate incomes if they separate waste as a first phase. This money can be used on better waste collection service, or start building their own companies on waste treatment. So, a key finding is that both municipalities have to start projects on waste separation.

\section{REFERENCES AND LEGAL ACTS}

ABDALQADER, A. \& HAMAD, J., 2012.Municipal Solid Waste Composition Determination Supporting the Integrated Solid Waste Management in Gaza Strip. International Journal of Environmental Science and Development, Vol. 3, No. 2

ANNE MATTER, A., DIETSCHI, M., ZU, C., 2013. Improving the Informal Recycling Sector through Segregation of Waste in the Household - The case of Dhaka, Bangladesh. Habitat International, Volume 38, pp. 150-156

ARMIJO, C., OJEDA-BENÍTEZ, S., RAMÍREZ-BARRETO, E., 2003. Mexican educational institutions and waste management programmes: a University case study. Resources, Conservation and Recycling 39, 283-296.

BUENROSTRO-DELGADO, O., 2001. Municipal Solid Waste: Perspectives from a Multidisciplinary Research.
Universidad Michoacana de San Nicolas de Hidalgo, Mexico.

ERIKSSON, O., M. CARLSSON REICH,. FROSTELL B., BJO"RKLUND A., ASSEFA G.,. SUNDQVIST J.-O, GRANATH J., BAKY A., THYSELIUS L., 2005. Municipal solid waste management from a systems perspective Journal of Cleaner Production 13, 241-252

GROSSMANN, D., HUDSON, J. F., \& MARKS, D. H., 1974. Waste generation models for solid waste collection. Journal of the Environmental Engineering Division, 100, 1219-1230.

INE, 1999. Solid Waste Minimization and Environmental Management. National Institute of Ecology. SEMARNAT, Mexico.

Kosovo Environmental Protection Agency, 2008, State of Waste Report, Kosovo 
Kosovo Environmental Protection Agency, 2018, State of Waste Report, Kosovo

MEDINA, M., 1997. The effect of income on municipal solid waste generation rates for countries of varying levels of economic development: A model. Journal of Resource Management and Technology, 24(3), 149-155, 1997

NIGERIA BABATUNDE B. B., WOKE G. N., VINCENT-AKPU I. F. ATARHINYO E., AHARANWA U. C, ISAAC-JOE O., GREEN A. F., 2013. Comparative analysis of municipal solid waste (MSW) composition in three local government areas in Rivers State, African Journal of Environmental Science and Technology, Vol. 7(9)

SEO, S., ARAMAKI, T., HWANG, Y., HANAKI, K., 2004. Environmental impact of solid waste treatment methods in Korea. Journal of Environmental Engineering Div., ASCE 130 (1), 81-89.

SHAH, K.L., 2000. Basics of Solid and Hazardous Waste Management Technology. Prentice Hall, Upper Saddle River, NJ, USA

STRANGE, K., 2002. Overview of waste management options: their efficacy and acceptability. In: Hester y, R.E., Harrison, R.M. (Eds.), Environmental and Health Impact of Solid Waste Management Activities. Royal Society of Chemistry, Thomas Graham House, Cambridge. pp. $1-52$

Statistical office of Kosovo (https://askdata.rks-gov.net/) VISVANATHAN, C., 2011. Bussiness and Employment Oportunities in Waste Management and Recycling in Asia. Waste Management Journal, Volume 31, pp. 10831084

WERTZ, K.L. 1976. Economicfactorsinfluencing households' reproduction of refuse. Journal of Environmental Economics and Management, 2, 263-272. 